\title{
Making Lives, Making Communities: Deaf Youth in Benin
}

\author{
Carsten Mildner
}

\section{Becoming Deaf}

An adage of deaf rights movements that is commonly expressed in Benin says "les sourds peuvent tout faire sauf entendre": the deaf can do everything but hear. Physically, that is plausible and can serve as a good basis for equality claims and critique of discriminatory practices. But it is also true that, phenomenologically, the non- and hard-of-hearing experience family, community, and society very differently than the hearing, who to the deaf constitute an emic "other" that includes persons with other disabilities. Adhering to social models of disability (see Shakespeare, 2010), I do not intend to present deafness as an essential "differentness" (see Neubert \& Cloerkes, 2001) that fundamentally separates deaf people from the presumably "normal." Rather, the differentness of deaf persons is socially constructed as well as fashioned by the deaf themselves, "looped," so to speak, through a continual process of change and adjusted perceptions (Hacking, 2011, p. 297f). The physiological aspect of deafness is—as with

C. Mildner $(\bowtie)$

Bayreuth International Graduate School of African Studies (BIGSAS),

Bayreuth, Germany

e-mail: Carsten.Mildner@uni-bayreuth.de

(C) The Author(s) 2020

M. L. McLean (ed.), West African Youth Challenges and

Opportunity Pathways, Gender and Cultural Studies in Africa and the Diaspora, https://doi.org/10.1007/978-3-030-21092-2_6 
other disabilities - but one of many facets of being deaf. In Deaf studies, the normalization discourse is identified as reducing deaf people to their physiological impairment and forcing them into the standards of the hearing majority society (Davis, 1995). Deaf people themselves-in Benin and beyond (for Japan see Nakamura, 2006, p. 184, for Ghana see Kusters, 2015 , p. 95) — practice a kind of segregation from within, othering themselves from the hearing by forming an exclusive peer group. This exclusive group is considered a deaf community, or as is critically discussed in the literature, a complex of "Deaf culture/community/world" (Kusters, 2015 , p. 20)-a community of shared experience of social disability, of cultural similarity, and, most of all, of a shared language. In Benin, there is no unified, postulated, notwithstanding formalized, deaf community or culture, but there are several groups and spaces that serve as communities to the respective members.

This chapter explores how deaf youth in Benin can or cannot choose to enter these communities. In the first section, I identify and outline four major dimensions that frame the possibilities of being deaf in Benin: physiological, geographical, cultural, and social. As the discussion will show, these dimensions are immensely intertwined and entangled. To illustrate the possible interplay of these four dimensions in the lives of young Beninese during the period of transition from youth to adulthood, in the second section, I introduce three deaf individuals as case studies that will be preceded by a short discussion of youth concepts. All three young people are members of deaf communities, but their paths of entry, kinds of belonging, and appreciation of and by the respective communities are quite different. These case studies do not purport to cover all aspects and potentialities of moving through life as a deaf youth in Benin; but viewing them side by side yields a perspective on how the conditions and frames can work out for deaf young people. The phrase "making lives" in the title is inspired by Ian Hacking's (2011) "looping effect" and his thoughts on "making up people" (Hacking, 2002, pp. 99-114), emphasizing the inseparability of self-determining and being determined in the process of becoming a social person. In other words, "identity is a byproduct of modes of interrelationships" (Jackson, 1995, p. 118, italics in original) and therefore inevitably social (cf. Jenkins, 1996). Looking at this particular segment of West African youth, I explore some of the dynamics and challenges at stake for young deaf individuals seeking to take advantage of opportunities and overcome obstacles in making their lives. 


\section{Notes on Methods and Terminology}

This chapter is based on ethnographic material gathered during 12 months of anthropological field research in 2016 and 2018 in Benin. ${ }^{1}$ My research project broadly explores questions of identity, belonging, and community among the deaf in Benin, focusing on the interplay of the physical and social experience of deafness. I conducted participant observation in families, schools, workplaces, churches, festivities, and daily chores. This "thick participation" (Spittler, 2001) led to informal conversations and reflections, which were more common than recorded interviews. That is also because the documentation of interviews in sign language required setting up a video camera, which formalized the situation even more than the infamous tape recorder. I used the camera for longer narrative interviews, mostly with people I already knew quite well. I spoke, visited, and observed deaf people of practically all ages, who I got to know mostly through snowball sampling, with a slight gender bias toward male deaf persons. Most women I talked to were confident, interested, and open; I did not notice a particular restraint because they were interviewed by a male anthropologist, at least not after we got to know each other.

Readers who are familiar with Deaf studies will have noticed that I do not use the capitalized $D$ when referring to the deaf in Benin. Deaf studies scholars and activists claim that being deaf is rather an experience of being a linguistic minority than an experience of disability. Therefore, Deaf culture and Deaf are written with a capitalized $D$, as you would capitalize other linguistic identity markers such as French, Fon, or Franconian (Ginsberg \& Rapp, 2013; for further discussion see McIlroy, 2010; McIlroy \& Storbeck, 2011, p. 498). The question of whether or not and how the deaf in Benin ascribe to "Deaf culture" is one that goes beyond the scope of this contribution. I chose to use a small $d$ here as the conventional notion of Deaf culture is not widespread, and sign language is not a useful identifier of the deaf in Benin, as only a minority of the deaf know the Francophone West African variant of American Sign Language (ASL) (Kamei, 2006; Nyst, 2010). In countries where Deaf culture movements are strong-such as the United States (Lane, 2010, p. 83) or Japan (Nakamura, 2006, pp. 22, 185) - it is usually the hereditary born deaf who are seen as the truest, "purest" Deaf (Nakamura, 2006, p. 2), as their

\footnotetext{
${ }^{1}$ My field research was funded by Studienstiftung des deutschen Volkes and Bayreuth the International Graduate School of African Studies. I am very grateful to Hanna Lena Reich and the editors for their comments on this chapter.
} 
first language is sign language. The rate of hereditary deafness in Benin, is, however, quite low-a factor that leads to a different physiological, and phenomenological, vantage point.

\section{Physiological Dimension}

The rate of hereditary deafness is very low in relation to deafness caused by illness or questionable medication during pregnancy; complications at birth; overdose of vaccination, antibiotics, or other medication of the newborn; complications of different diseases like malaria; and the most common cause, meningitis (Ette-Akre, 2012, p. 32; Vodounou, 2008, p. 62). Even though hearing loss is often attributed to witchcraft, curses, or breaching of taboos by the deaf person's parents (for Ghana see Kusters, 2015, pp. 108, 209), many hearing Beninese believe that deafness is hereditary. It could be that cultural and medical explanations are being conflated, or that both are equally respected and feared. On the physiological level, this means that parents tried to prevent their deaf children from marrying other deaf for fear of having deaf grandchildren (see also Kusters, 2015 , p. 31). As hereditary deafness is usually recessive, this means that few deaf children experience having deaf parents (Aoki \& Feldman, 1991). The core group that shares the "same" experience of generational and cultural deafness, thus, does not exist as such. Instead, there are several ways and moments in life to become deaf; therefore, there are manifold ways deafness plays out in a person's development.

Children who are born deaf or deafened prelingually, that is, before speech acquisition, have no experience of a spoken mother tongue. However, persons who are deafened postlingually, that is, after having acquired speech, usually around the age of two to three years, do have a general idea of what speaking is and that movements of the mouth produce sounds that are words that have meaning. The older a person is at deafening, the more she is familiar with language and might continue to speak for the rest of her life. A child or teenager who becomes deaf may acquire or learn a different social role as a deaf person and socialize into the deaf world. People who deafen after childhood or youth might not consider themselves deaf at all, as they deafened after being fully socialized in the hearing world. As that is a very individual experience-and sometimes a choice - there is no way of generalizing a certain age when this switch occurs. The French and Fon words for deaf-sourd and tokounon- 
are applied to all kinds of severe hearing impairments and do not designate the degree of hearing loss.

The postlingually deafened, les devenus sourds, are potentially more able to learn lip reading in those languages they acquired before deafening than their prelingually deaf peers, les sourds profonds or les nés sourds. On the one hand, this makes the deafened more able to communicate with the hearing, to the extent that sometimes people would not even notice or believe that the person is deaf. Through lip reading and glimpsing into the hearing epistemology and ontology to varying degrees, the postlingually deaf have more access to the (hearing) world than their prelingually deaf peers.

Although a social approach to disability focuses on the constructivist aspects of disability and deafness, physiological dimensions have to be taken into account regarding their respectively different opportunities to actually become social in the first place. In an existential reflection of the question of essence and existence, Ian Hacking (2011) commented on the limits of social constructionism that "existence may precede essence for the lucky, but there is a vast dead weight of essence that presses down on most human beings" (p. 284). Those physiological impairments are deepened socially by the insufficient support from educators in deaf schools. Yet, the place where deaf people can learn to be social and to communicate is the school-the core space of community and identity construction. To get to school, however, you need to be somewhere there is a school.

\section{Geographical Dimension}

Ways of becoming deaf socially are shaped by the geographic location where a person happens to have been born. This refers to the rural-urban dualism and also to the sheer coincidence of growing up near or far from a deaf school.

In Benin, there are nine primary schools for the deaf: one in the capital Porto Novo, three in the biggest city Cotonou, two in the villages Sé and Pèporiyakou (near Natitingou), and one each in the towns of Allada, Bohicon, and Parakou. Most of these communities are in the south; only Parakou and Natitingou are located in the north. If a deaf child lives in a village in the north, she is thus not so likely to have access to, nor is her family likely to have knowledge of, deaf schooling and its opportunities. Due to the lack of qualified teachers, the schools do not necessarily offer quality education. However, it is in deaf schools that deaf children meet 
their deaf peers and sometimes realize for the first time that they are not the only deaf persons in the world, an important step for a deaf person's identity development (Vodounou, 2008, pp. 90, 93).

The schools constitute "deaf spaces" that serve not only as spaces of community and identification (Kusters, 2015), but also as "safe spaces" for deaf children. Although there is no widespread mockery of deaf people from adults, some deaf adults have childhood memories of being mocked by other children in the neighborhood. For instance, other children would take leaves in their mouths to communicate that the deaf children were viewed more like goats and other animals than as humans. Childhood experiences such as these distance the deaf child from the hearing world. Inside deaf schools, children are shielded from being denied their humanity. There is also the advantage that in the surrounding community deafness is less likely to be perceived as an anomalous condition attracting mockery. The fact that some schools are integrative and include both hearing and deaf children, or sometimes just some hearing siblings of deaf children, strengthens this effect.

Even if deaf children do not enter school, they can become part of a deaf community by meeting other deaf people. This is more likely in urban spaces than in the village, simply because the absolute number of deaf people in urban areas tends to be larger. In Parakou or Natitingou, where the schools have been established not much longer than ten years, there is a non-standardized way of signing among the deaf who were born before the schools existed. The deaf meet at deaf spaces such as deaf people's workshops or run into each other in the market or places where football matches are broadcast. The deaf community thrives most in Cotonou, where the first deaf school was created alongside the deaf church in 1977. Also, the two other primary schools and the collège (secondary school) facilitate contact and friendships. Furthermore, leisure activities and institutions like a deaf football club require a critical mass of people around the same age and gender that is more likely to exist in urban centers than in rural areas. The three individuals in the life story sketches all lived in Cotonou for the better part of their youth.

\section{Cultural Dimension}

Another factor in the rural-urban dualism is that beliefs in magic and witchcraft are becoming less dominant in the cities while they thrive in small towns and villages. The basic notion that "the dead are not dead" is 
widespread. Beninese people tend to say that this is a cultural reality rather than a religious belief. In any event, regarding the deaf, the supernatural explanations are relevant to the issue of stigma. In Benin, a child's deafness is oftentimes explained by her parents having been cursed by witchcraft or having violated some taboo or obligation toward the ancestors. Following this explanation, the deaf person herself is never the culprit but the passive victim. The ones who have failed to respect a taboo, the ones who were supposed to be punished or attacked, the guilty ones, are the parents and not the child. In theory, this means that it is not the deaf person who is stigmatized, and that deafness is nothing for the deaf person to be ashamed of. In sociocultural terms, deafness falls into the broad category of illnesses, mishaps, and disabilities commonly understood to be entangled with magico-religious practices. The downside is that, fearful of what others might think, some parents literally hide their deaf children away. I did not encounter deaf children who were being hidden away by their parents, but I heard many stories of activists and school employees who tried to convince parents to take their deaf children out in the open. Often these accounts involved parents of deaf children who were said to be rich and concerned that their child's deafness would be perceived as confirmation and evidence of immoral practices that made their wealth possible. This is a widespread view in some West African communities, where "[witchcraft] accusations were directed at those individuals and families who, in the pursuit of economic success, appeared most competitive, greedy, and individualistic in their social relations" (Scheper-Hughes \& Lock, 1987, p. 24; see also Igwe, 2016).

\section{Social Dimension}

Arguably, with respect to the transition from youth to adulthood, the crucial experience that Beninese deaf have of their deafness is social. The more deaf children get in touch with other deaf children or institutions for the deaf, the more likely they are to enter a deaf community and grow to be deaf in the sense of a social being. But the creation of networks and community requires a certain number of deaf people who can get in touch. Particularly in rural contexts, though, the creation of and access to deaf communities is rarely possible.

The census data on disabled people is considered unreliable by the Fédération des Associations des Personnes Handicapées au Bénin (Federation of Associations of Disabled People in Benin), the umbrella 
organization representing people with disabilities and their interests on the national level. In 2003, Kiyaga and Moores stated that "there are neither reliable data nor reliable estimates of the number of school-age deaf children in sub-Saharan Africa. No country in the region has ever counted its deaf population in a census" (p. 21), which, to my knowledge, stands true to this day. The World Health Organization (2018) estimates that on a global scale "up to five out of every 1000 babies born are born with hearing loss or acquire it soon after birth." The cases that are caused later in childhood, adolescence, and adulthood have to be added to the $0.5 \%$.

It is remarkable that in every village I visited in the north, I found one, two, or three deaf people, or at least heard stories about deaf inhabitants. There is no special education for deaf children in the village (except for the two village deaf schools in Sé and Pèporiyakou). Instead of going to school, they learn the gendered work as any other child would: the girls stay with their mothers, sisters, and other female relatives in the homestead, while the boys - after a certain age-follow their fathers and brothers to the fields. Most learning of village work is not acquired through explanation but occurs through observation and imitating. Parents and neighbors of deaf children I met in the villages assured me that the children were good workers.

Deaf children in the village barely go to school, but many hearing children do not attend the chronically understaffed and underfunded public village schools either; they too are expected to work. The lifeworld in the villages that is structured by age, gender, and work further undermines a feeling of "deaf similitude" (VanGilder, 2016, p. 148; see also Kusters, 2015 , p. 92f). A deaf teenage boy and a deaf woman in her 30 s would not necessarily have any shared spheres of life. Hence, given the likelihood that they each are experiencing different degrees of deafness, and that there is no standardized sign communication, what would motivate them to practice or create a shared identity?

In the towns-or in the deaf schools in Pèporiyakou and Sé-the situation is quite different. While the standard of education in the deaf schools is not particularly good, the deaf children learn to sign mostly in the breaks between or after class. The teachers-almost exclusively hearing individuals-have varying degrees of competence and interest in sign language. There is no special education nor a financial encouragement to teach in deaf schools. In the private schools, which are the majority, the teachers earn little more than the minimum wage of 40,000 FCFA (about \$70) per month-if they are lucky enough to receive the salary at all. Teachers' 
salaries in the two public schools are higher, but the authorities do not employ enough teachers. Some substitutes are paid for directly by the parents of deaf pupils.

Similar opportunities are offered by the two deaf churches in Cotonou, where the congregations are made up of deaf teenagers and adults, some of whom have been to school and others who have not. Since the deaf churches were established, part of their mission has been to teach sign language, primarily for the sake of preaching the word of God (Kamei, 2006; Kiyaga \& Moores, 2003; Nyst, 2010). ${ }^{2}$

Aside from those two institutions, churches and schools, there is the sphere of informal deaf space at the workshops of artisans, craftspeople, and purveyors. Deaf craftspeople often take deaf apprentices. Their workshops turn into deaf spaces, where deaf people work and learn, but also gather, chat, and socialize. These spaces are more numerous in cities than in smaller towns or rural settings.

By becoming part of these communities, deaf people have the profound experience of discovering that they are not alone in their condition-they are not the only deaf people in the world (see Nakamura, 2006, p. 19; Vodounou, 2008, p. 90). They can express ideas and get to know people that they can ask for advice, get information and-seemingly the most important thing-gossip. It is only in these communities that they can learn basic abstract concepts like the existence of Benin as a country among others, the meaning of religion, or other topics that cannot be discussed in rudimentary gestural communication with their family or neighbors. The prelingually deaf also get to know postlingually deaf who can explain to them how the hearing world and society works. As unifying as this community may potentially be, it also socially stabilizes the distinction I mentioned under the physiological dimension: the experience and knowledge of the postlingually deaf can lift them above the prelingually deaf and create paternalism and subordination.

Another crucial social aspect of becoming a deaf social being within the deaf community is hierarchy. Founders of schools, priests, and also those young deaf people who were the first to obtain higher education or are successful in economic activity are known and respected authorities that are sometimes even feared in the community. Being attached to one church, to one school, to one association, thereby to one head of either

\footnotetext{
${ }^{2}$ See also the articles by Andrew Foster on the website of the Christian Mission for the Deaf: www.cmdeaf.org
} 
institution, might determine how one relates to other authorities-based on the relationship the respective authority has with the others-or if they relate at all. The question young deaf are faced with is how to integrate into these networks and hierarchies. Shall they take the place the respective authorities allocate to them, or shall they be "vanguards" and "vandals" (Abbink, 2005) and challenge the structure of the communities? These questions will be of importance in all three life story sketches that follow.

\section{Pathways to Becoming a Deaf Adult}

In the previous section, I have shown the versatility of "becoming deaf" in Benin and how that process is interconnected with both the sociocultural context and the physiological, individual experience. In this section, I examine how these challenges can be experienced or "navigated" (Vigh, 2006,2010 ) by young people seeking their position in life and community. The notion of maneuvering and navigating captures the set of actions youth take to cope with difficult and obscure contexts, in order to make a living and make their lives (Christiansen, Utas, \& Vigh, 2006).

Now, for the purposes of this study, whom do I categorize as youth? I do not intend to take on the challenge of developing a globally valid and inclusive perspective on youth (see Philipps, 2018, p. 1); nor do I wish to uncritically generalize and project youth models from the Global North (Philipps, 2018, p. 4) onto the setting in Benin. Instead, as used here, the term youth refers to persons considered les jeunes by members of the Beninese deaf communities included in this study: Deaf individuals who so identified, or were so identified, were in secondary school or apprenticeship, had not yet achieved professional and familial establishment and were roughly between 13 and 30 years of age. ${ }^{3}$

Age as such, however, is not crucial when defining young peoplerather youth is an "imprecise group [of which] definitions compete according to circumstances, events or calculations" (Balandier, 1985, p. 87 as cited in Le Meur, 2008, p. 211). It depends on the achieved

\footnotetext{
${ }^{3}$ The United Nations Educational, Scientific and Cultural Organization (UNESCO) (2017) uses 15 to 24 years as the age brackets for youth and defines it as "a period of transition from the dependence of childhood to adulthood's independence and awareness of our interdependence as members of a community," that is, a time of finding one's place in community and society. For the African Union (2006), the words youth and young people refer "to every person between the ages of 15 and 35 years" (p. 3).
} 
stages in life-for instance, graduation from primary school, receiving an apprenticeship diploma, foundation of a family, or settling professionally for the first time- "moving on to adulthood," as Le Meur (2008) notes in a case study on central Benin (p. 229). The notion of incompleteness is one that I witnessed being reproduced by the elders in the deaf community in Cotonou.

The idea of youth as a contingent category is carried further by Jean and John Comaroff (2005), who emphasize the historicity and volatility of the concept - noting that youth are not born but "made by historical circumstances. And rarely as they like" (p. 24; see also Christiansen et al., 2006, p. 11). The social construction of youth is just as true for the deaf. They face expectations they may choose to meet or not. In the literature, this tension is discussed in a polarity between subordination and rebellion, of being Makers \& Breakers (Honwana \& de Boeck, 2005; see also Abbink, 2005; Le Meur, 2008), of signifying hope and threat to established structures (Comaroff \& Comaroff, 2005, pp. 20, 24; Martin, Ungruhe, \& Häberlein, 2016).

Youth have been discussed as occupying "innovative, uncharted borderlands in which the global meets the local" (Comaroff \& Comaroff, 2005, p. 27f), and as being between childhood and adulthood (Le Meur, 2008, p. 229; UNESCO, 2017). In such an unascertained position, they are in a situation of potentiality, being and not being. Reflecting on this liminality from the standpoint of disability, Patrick Devlieger (1999) proposes that disability be understood as an interstitial category, as disabled people "are situated (and situate themselves) in between the structural categories that define cultures" (p. 299). Deaf youth, then, can be considered to be in a double bind-a compounded intersectional situation.

Comaroff and Comaroff (2005) observe that navigating borders and structures of marginalization is a universal challenge for young people, but the ways in which they experience and face this challenge is not homogenized (p. 27; see also Philipps, 2018, p. 4). Likewise, there is no globally homogenous deaf culture (Erting, Johnson, Smith, \& Snider, 1994; Friedner \& Kusters, 2016; Monaghan, 2003), nor are national and regional deaf cultures and communities homogenous (Padden, 1980, p. 91). Orientations and navigation in these ambivalent and miscellaneous terrains are challenging for both youth and deaf, and maybe even more so for deaf youth (see also Friedner, 2015, p. 16, for orientations and conflicts of deaf youth in Bangalore). With the three life story sketches that follow, I will discuss a few shades of experience of deaf youth in Benin to 
show how different pathways unfold within the same arena of challenges and opportunities. All names are anonymized.

\section{On the Edge of a Deaf Community: Élie}

I met Élie for the first time in June 2016 when he was about 16 years of age, finishing primary school in a center for the deaf in Cotonou. He was prelingually deaf and very expressive and fluent in signing in a logic and structure that comes naturally to the born deaf (Kusters, 2015, p. 7; Sacks, 1989, p. 77f). As he had little grasp of French grammar, which is the basis for the general way of signing in Benin (Kamei, 2006), formal interviews were a complicated undertaking. Some questions and reflections on his life course and personal history were not understandable to him or I could not make myself understood. Instead, I got to know him through conversations during walks in the neighborhood, going for runs together and chatting at the beach, and a lot of participant observation in the deaf center where I lived for a few months in 2016. In 2018, while he was an apprentice at the tailor workshop on the same premises, I went there almost every second day to chat, interview, participate, and observe life and work in the center. We did not stay in touch between my two field trips as he had neither phone nor internet.

Élie was born in northern Benin; his date of birth is unknown, and he did not have a birth certificate or any legal documents. It is not even clear if he was born as Beninese or Nigerien. His name was not given to him by his parents, but by Catholic nuns who found him after his parents abandoned him at the age of about two. There is no reliable information on whether Élie was born deaf or deafened shortly after birth, nor on details of the first years of his life. The nuns placed him in a deaf school in Parakou, run by an evangelical church, directed and taught by hearing people. Joachim, the deaf director of the center in Cotonou, met Élie in Parakou at a sports event, took him south, and enrolled him into his school. I do not know what the nuns thought of this, but from other comparable situations (see Omolayo later in this story), I know that hearing people often think that the deaf should be with "their" people, with "their brothers and sisters," so Joachim's initiative was probably welcomed.

Élie was the only deaf child who stayed in Joachim's boarding school in Cotonou during the vacation, as he was practically an orphan with no connections whatsoever to his biological family. He became the foster son of Cathérine, Joachim's second deaf wife, who took care of the boarding 
school children's hygiene and canteen. Cathérine stated that he was now her son, whether she wanted it or not, because he had no one else. Although there was no formal adoption, he found food and shelter with the family and was regularly sent to complete different chores: buying small things, delivering messages, helping in the household, and surveilling the boarding school children during the school year. It is quite common in Benin to take distantly related or unrelated children into a household in exchange for support, sometimes leading to the children actually becoming part of the family (Alber, 2018). Nonetheless, Cathérine treated Élie differently than her own three hearing children regarding affection, attention, and care. For example, he would be sent to do chores more often, would receive worse food than her biological children, or would not be taken along with them to church or other festivities involving transport and other costs. Joachim would not call Élie his son, denying a kinned relationship (cf. Howell, 2003). Yet he felt responsibility and had the authority to make decisions over Élie's life course.

Élie had been in the center already for a few years before I met him in 2016. Due to the lack of a last name and a birth certificate, he could not take the final primary school exams (certificat des études primaires, or CEP) and hence was not admitted to secondary school. He wanted to become a teacher for the deaf, which was not possible without further education. After some time of reflection about what to do, Joachim finally made him an apprentice in the tailor's workshop in the center.

Élie continued to sleep in the center all year, being the oldest "son" and learning in the workshop. On the side, he helped an elderly hearing woman in the neighborhood set up her stall in the streets, where she sold deep fried yams, breadfruit, aloko, sweet potatoes, and mashed bean beignets. In return he would eat or occasionally get a little money from her. She had already supported other deaf persons in the past years and was consequently known among the deaf as Maman Vadim. In Benin and other African societies, mothers are often referred to as the mother of their first born. Vadim, a deaf painter, was not actually Maman Vadim's son but her son-in-law. Among the deaf, she became his mother through the care she gave to him (see Goody, 1982; Howell, 2003). Also in Élie's case, she cared for him beyond food by arguing with Simon, the deaf tailor and instructor, about getting Élie more involved in the actual work. Apprenticeships in Benin usually start with the apprentice watching the patron's work for several months while doing small chores, before touching the actual work for the first time. When Élie had only attached buttons 
for almost a year in 2018, Maman Vadim approached Simon, quite expressively, to stop wasting Élie's time and really start teaching him.

As the only permanent resident of the center who was not part of Cathérine and Joachim's family, Élie took over a particular role. He knew the place and the people. He must have felt very much at home. At the same time, he was always excited about people dropping by-other deaf people, hearing and deaf French volunteers, me as a permanent visitor, or also my mother who visited me in the field in September 2016. He insisted on sending her a video of him greeting her for her birthday in July 2018. Often when we hung out in front of the workshop, watching people walk by, or when getting food, taking a stroll in the neighborhood, or running to the beach, he would just ask random things about the French volunteers he had met in the center, my mother, or the elderly lady I was staying with for some time in Cotonou. It seems to me that this listing of names and acquaintances is a kind of outreach into the world, throwing out anchors to fix him in a virtual network. Acquaintances in Cotonou, Benin, and beyond seemed to be an orientation, maybe a status, or fixed stars for social navigation. One might say that he could not make much use of these landmarks at the time, but part of social navigation is keeping open potentialities. For example, he kept collecting telephone numbers of people he met, as well as friends of mine who came over to visit the center. $\mathrm{He}$ did not have a telephone. But, you never know.

Despite working his way through two deaf schools and his apprenticeship at a deaf space, Élie's access to the wider deaf community is relatively limited. In the family, just as in the workshop, he was treated as an inferior and did not receive a lot of respect or recognition. His lack of any financial means or real income kept him from getting to the deaf church in another part of town or coming often to deaf football training. The deaf church has no means to support the cost of transportation of any member but the priests, who also preach to the deaf in other cities. ${ }^{4}$ The majority of the deaf footballers either were some years older than Élie or had formed another peer group of secondary school students. He was inferior in both age and education. He got some recognition, however, for being a good runner and taking part in different charity runs, winning a marathon in

\footnotetext{
${ }^{4}$ It is often said in West Africa that the best way to become rich is to found a church. From my experience, I suggest not to found a church for people with disabilities. There is not much money to be made from them.
} 
Parakou in February 2018. The fact that he was mastering an individual sport instead of a team game seems quite characteristic.

His position changed slightly in July 2018 when a new deaf boy, Omolayo, around 16 years of age, arrived in the center. His Nigerian parents were concerned that he was roaming the streets all day and all night, afraid of him becoming a criminal. His parents paid Cathérine for food so that he could stay in the center. He started an apprenticeship in the tailor's workshop, based on the hope that living with other deaf people, "his brothers," as Omolayo's father said, would calm him down. Given that he was a lot harder to handle than Élie, Cathérine remarked appreciatively that Élie was too calm and confident to be provoked by Omolayo's offenses. Good for Omolayo, she said; if Élie one day would fight back, he might kill him. This was also, weirdly, an appreciative comment, as she acknowledged him as a strong young man.

From an abandoned disabled child to an apprentice with a small but diverse social network, Élie came a long way, going through different spaces of deaf sociality. In that deaf sociality, he found deaf adults who would take over care obligations. He did not become a member of the core community around the deaf church. After his apprenticeship, new contacts and support will be necessary to find a job, to found his own workshop, and to start a family. But with his 18 years of age, youth is still long.

\section{Into the Deaf Family: Kiva}

I got to know Kiva in the deaf church in Vêdoko, a neighborhood in Cotonou, when she was 26 years old. She and her deaf husband were very active members of the congregation. Although the church did not have official positions for women of importance-unlike the male priests, the precentor, the prayer instructors, custodians, even cleaners-she was close to a "soft power" of the congregation. While Nicéphore, her husband, served as the precentor and thereby was a confidant of the head priest, Homère, Kiva was close to Homère's wife, Wilhelmine, who ran a boutique in the church's building where pupils from the deaf school around the corner would come during the day to purchase candy. Kiva cleaned the boutique and ran it when Wilhelmine could not be there. I often met her there to chat; we did a video-taped interview, and we often talked after church on Sundays. I also visited Kiva and Nicéphore in their home in the inner-city swamps in the Ahogbou neighborhood. 
Born deaf in Togo, the only child to her father's second wife, Kiva and her parents fled during the reign of Gnassingbé Eyadéma (president after the 1967 military takeover and until his death in 2005), which she described as a time of war. Her father was killed on the getaway. She and her mother settled in Porto Novo, Benin, where they had relatives. There her mother sent her to a private deaf school that had opened in the 1990s. She stayed until quatrième (equaling the eighth year in school). At some point, her mother and her family could not pay the tuition anymore, so around the age of 15 , she started an apprenticeship as a hairdresser with a hearing patronne. Halfway into her apprenticeship, her mother moved to Womey, a village-like neighborhood on the outskirts of Cotonou. It was then that she started frequenting the deaf church, even though it was a long ride from Womey. Before that she had accompanied her mother to a Catholic church where she never understood anything. Her mother supported her participation in the evangelical deaf church, believing that it was good to attend any church at least. It was in church that she met Nicéphore.

They both realized, after praying a long time for advice, that God wanted them to marry. Their mothers-Nicéphore's father had died as well-hesitantly agreed. Nicéphore's mother told me in an interview that she was worried they would have deaf children. For Kiva's mother, the deafness was not as big a problem as the fact he was from Ouidah, the capital of Vodun in Benin (see Rush, 2013). Not only was she suspicious of the "heathen" culture, but she was also afraid because of prejudices against people from Ouidah in general. The interethnic incompatibilities were more relevant for her than the deafness. Eventually it was the priest of the deaf church who went to see both mothers and convinced them, arguing that Nicéphore was a good Christian, a good man, and telling them that their grandchildren would not be deaf-using his own hearing children as proof. His son would come along to those kinds of meetings to interpret. The only condition was that they shall both finish their apprenticeships before marrying.

Thus, in 2013, Kiva and Nicéphore were the first couple to marry in the newly built deaf church. The event took place at the same time as the opening of the new church building. Photographs of the ceremony and party contribute to the collective memory of the congregation.

In 2014, at age 24, Kiva gave birth to her first son. After he turned 2, Kiva and her husband gave him to her mother and her family, so he could learn to speak. This is a common practice among deaf couples, as they 
would not be able to teach their children language. Sign language does not get the same mother tongue recognition in Benin as it gets in other deaf communities (see, e.g., Lane, 2010, p. 83; Nakamura, 2006, pp. 1-2). As mentioned above, the practice of giving children to be raised by other family members for various reasons and to varying degrees is known among hearing Beninese as well (Alber, Martin, \& Notermans, 2013). Kiva's second son was born in 2016 and was always by her side during my research in 2018. He did not speak a word but understood the sounds his parents uttered - they did not sign to him-better than words other people spoke to him. At some point, she told me, she would also give him to her mother or an aunt so that he could learn to speak.

Although Nicéphore's mother lived right around the corner from the deaf church, a lot closer than Kiva's mother, she was not involved in the children's education and barely saw Kiva at all. Instead, Kiva spent all day from Monday to Saturday in the boutique of Wilhelmine. She cleaned, sold, stocked up, and took care of her son. The boutique was very much a deaf space as Kusters sees them: many deaf people dropped by for a chat and a lemonade during the day. As a deaf school was right behind the building, the boutique also offered a contact zone for the deaf children. Most of all, though, people came by to see and consult Wilhelmine, who appeared to take over a mother's role for the entire congregation. She became a mother figure for Kiva, giving advice on how to raise her sons, giving her a job opportunity, wondering with her how to contribute to the family income-Nicéphore's work as a carpenter on different construction sites does not provide for more than a very basic budget.

Kiva told me that she had no contact with any hearing people whatsoever-overlooking the contacts with her maternal family. Her uncles sometimes gave them some money, but she did not recognize that as being enough. From her family, she expected nothing but financial support it seemed. From the deaf, she did not receive any financial support, instead a position among them and recognition. Always being around Wilhelmine, she slipped into a position of passive importance that she shares with only a handful of other members of the congregation of about 80 frequent members.

Having left her geographic place of origin, it seems that Kiva also cut ties with her hearing social origins. As soon as she accessed the deaf world around the church, she dived in and enjoyed the acceptance, recognition, and belonging that she never experienced in the hearing contexts of family, the Catholic church, or the apprenticeship with hearing patronnes. She 
found familiarity and belonging in church, but even more so in the deaf space it constitutes than in the spiritual message. Among the deaf, the community around the church was one of the most acknowledged ones, and through being there, through participating and receiving care from the church's mother figure Wilhelmine, Kiva's integration into church must have been a very "kinning" experience.

\section{Achieving Through and Beyond the Deaf Community: Isaïe}

In Nikki near Parakou in north eastern Benin, Isaïe was born the son of a Baptist priest in 1988. He went to a public school until he deafened from meningitis at the age of 12 . He switched to the deaf school in Parakou at first, before getting into the private lycée in Porto Novo with the help of Swiss donors. It was the only school in Benin where deaf people could get a higher education entry qualification (baccalauréat). He went on to study educational science and psychology at the Université Abomey-Calavi in Cotonou; in 2018 he was still waiting for his final certificates for his license (undergraduate degree). During his school and studies, he was financially supported by international donors, organized and channeled through Joachim, and assisted by Homère, the priest. Education in both the private school in Porto Novo and the public university cost far more than a low-income family could afford for their child. It was in the yard of Joachim's center in Cotonou that I met Isaie for the first time. As a postlingually deaf person, he speaks almost flawless French and his mother tongue Bariba. He can read lips, and sometimes people would not even notice that he has $100 \%$ hearing loss. I conducted several interviews with him, sometimes on video tape, sometimes on audio tape (I would then sign and speak at the same time so that I could hear my parts of the informal interviews on tape as well), as the tape recorder was more easily set up than a camera. I also lived at his place in Natitingou for some time, accompanied him to the Catholic school for the deaf where he works in Pèporiyakou near Natitingou, and spent a lot of time with him when he would visit Cotonou. Furthermore, we stayed in touch through Facebook and WhatsApp when I was not in Benin.

When he came to Porto Novo, Isaïe was about 280 miles from his family and integrated well into his deaf peer group in the boarding school. He did very well in school, as he said, but often got into trouble with teachers and the directorate due to his recalcitrant nature. When in Cotonou, he lived with Homère and Wilhelmine-just like their own children, as 
Wilhelmine would say. Even though he had no family ties or contacts in Porto Novo nor in Cotounou, he immediately found support-regarding both financial help and kin care-through the deaf community, just as Élie and Kiva did.

During and after school, however, Isaïe took a different turn. Instead of adhering to the smaller (Élie) or bigger (Kiva) deaf community, he questioned the discourses and practices of those communities in general. He was one of the few deaf Beninese-all in all less than ten individuals-who went to university. The education he received was much more advanced than what was available to the older authorities at their time of youth, taking into account that the first deaf class to receive a baccalauréat graduated in Porto Novo in 2009. Isaie's experience and performance of youth can then rather be seen in the light of recent discussions of African (and global) youth that present young people simultaneously as hope for and as a threat to their societies. People invest their hopes and resources into the young to provide for a better future, while at the same time they tend to complain about the lack of morals and the threat to the existent order of society or community (see Diouf, 2003; Martin et al., 2016). Youth can be described as a "fantasized or real factor of disorder or renewal" (Le Meur, 2008 , p. 211). This seems quite the role that Isaie took over in the Beninese deaf community. The older authorities invested in him, but they were displeased to discover that he would not envision the future in the way they expected he would and should (Diouf, 2003, p. 4). Rather, he spoke out against them publicly on Facebook - a central medium for many discussions within the deaf community. His criticism was directed against certain conservative evangelical positions that Homère took against the allegedly immoral behavior of Isaïe and other young deaf (cf. Diouf, 2003, p. 9), but also against some corrupt ways of leading deaf organizations and associations by Joachim and others of his generation. On the one hand, he proclaimed the need for young people's self-organization in opposition to "the old," while at the same time wanting to become a patron himself, wanting to take over responsibility for his "deaf brothers and sisters" who did not (yet) have the chances he had, thereby directing himself to the

\footnotetext{
${ }^{5}$ There are some other deaf people who studied in public or private universities. Those, however, received their baccalauréat in schools for the hearing and usually deafened so late that they saw themselves as members of the hearing world who just happen not to hear-I mentioned this in the physiological dimension above. To my knowledge, these non-hearing, rather than deaf, academics never showed up in church, deaf sports, or deaf community events.
} 
ones younger than him. That seems to be in line with Martin et al.'s (2016) insight that "the young people who are receivers today wish to become givers in the future" (p. 9). Becoming a giver then means becoming a patron, and thereby challenging the authority of the current patron. The authority of figures like Homère and Joachim was, however, solidified by the somewhat clientelist (cf. Le Meur, 2008, p. 229) networks of support and care they assemble around them-as can be seen in the stories of Kiva and Élie. Up until now, Isaïe has not been able to realize any of his endeavors. Following a scandal involving his alleged affair with a student at a rural school where he was teaching in 2015 , he had to get a new job. He found it at the Catholic school for the deaf up north near Natitingou. The geographic distance from the deaf communities, whose centers were mostly in Cotonou, left him no other channel but publishing reproachful messages on Facebook. He claimed that he got a lot of support from other young deaf people there, but the ones who supported him publicly by "liking" or commenting on his posts were mostly young deaf activists from other West African countries. The value of his messages to the Beninese deaf was being discussed in conversations and gossip in face-toface interactions in the communities-also because many deaf did not read well enough for his elaborate discourses. These renegotiations of his claims were literally beyond his reach. Ironically, or maybe even purposefully, the job in the north was mediated to him through Joachim's support.

\section{Conclusions: Making a Life in Deaf Communities}

The three people I introduced represent different pathways young deaf Beninese can take toward adulthood. Similar dynamics are at stake in each story - only to play out quite differently. In these conclusions I wish to focus on the question of belonging and affiliation on the one hand and the position within the youth discourses on the other. The question of belonging is particularly relevant for the deaf youth as their double bind condition means that affiliation to family, society or culture does not come naturally. Oliver Sacks (1989) stated that "deafness as such is not the affliction; affliction enters with the breakdown of communication and language" (p. 117). As communication with hearing families is difficult and deficient for the deaf, they need to find or create spaces where it is possible.

I have shown how Élie, Kiva, and Isaie all sought new affiliations when family did not provide the belonging and orientation needed. Élie was simply cut off from any birth family ties and kept at a distance by his 
informal foster family. Isaie seemed to gradually drift away from the hearing world in which he no longer felt comfortable. He once told me that he considered deafness as one of the gravest disabilities as it prevented him from fully participating in any given situation in the dominant hearing world. Although he was very competent in spoken communication, his communicative impairment felt like a hidden stigma (Goffman, 1963, p. 4lf). Among the other deaf-in school, in church-he was standing out in a positive way, being among those who were better able to participate in the hearing world. Thus, compensating for the stigma with a superior role among the deaf gave him a position that he would not find among the hearing, among his family.

Kiva's situation seems similar. It was not until she embraced the community of the deaf church that she realized how excluded she had been from the hearing community, even though she attended church services and worked among the hearing. But Kiva's and Isaïe's respective affiliations to the deaf communities played out quite differently. Kiva was included in the community in and around the deaf church. She married and introduced her children into the community, and she affiliated intensively with other deaf members of the congregation and did not even have contact with the hearing society anymore.

Élie might have had that chance, but the community he entered was not as inclusive as hers. The thicket of belonging seemed more filigree and less permeable; different categories of belonging-deaf/kin/age/experience-were at stake, whereas it seems that in church, it sufficed to be "a good Christian" and adhere to the rules and hierarchies to get to its core. Maybe that was why Élie was reaching out for hearing outsiders like Mama Vadim, French volunteers, or me more than others did.

Isaïe then became part of the broader deaf community, having his feet in many doors: the private school in Porto Novo, the deaf church, Joachim's center, and having access to the local and international deaf online communities. Mere affiliation and subsequent subordination were not enough for him though. With his rebellious behavior, he felt excluded based on his youth when trying to partake in the deaf community discourse. At the time of the publication of this chapter, his mission was still going on. After conflicts and confrontations, he had cut ties with the established communities and their authorities, while he had not yet become an authority himself among the young, which was absolutely his plan. 
The three individuals each represent a different shade of youth discourses briefly discussed above. Kiva adhered to the expectations and moral codes of the community authorities. Thereby she personified the above-mentioned hope of the elders to shape and reproduce the future in their own imagination. Élie, quite on the contrary, served as the prime example of the young who are a disappointment to the elders' hopes. $\mathrm{He}$ wanted to become a teacher, turn from receiver to giver so to speak, but the circumstances did not allow him to-yet, at least. Isaïe represented both the hopes for the future and the threat of change. His commitment to political participation in the community and his far from coy rhetoric made him the target of long lists of accusation along the lines of depicting the young "as dangerous, criminal, decadent, and given to a sexuality that is unrestrained and threatening the whole of society" (Diouf, 2003, p. 4).

And yet, through passive or active engagement with society, Kiva, Élie, and Isaie partook in the structural reproduction and transformation of the deaf communities. Their experiences suggest some of the ways in which the experiences of deaf youth in Benin confirm or scrutinize, and reproduce or reshape, their communities, thus constructing the frames within which their individual futures unfold. Regarding people's narratives, anthropologist Michael Jackson (2010) stated that "our lives belong to others as they belong to ourselves" (p. 137). When deafness is first and foremost seen as a social role instead of a medical or physical condition, it becomes clear that young deaf people's future lives are inevitably interconnected with the hearing world, but also with their deaf peers-older and younger. As double bind deaf youth, they are potentially excluded from their deaf communities as well as the hearing youth. The young deaf need to handle that social role of deaf youth which is "a position which is internally and externally shaped and constructed" (Christiansen et al., 2006, p. 11). But, however contentious the deaf communities might be-or might be portrayed by Isaie- the three case studies also show that the communities are there to take care of the young deaf when other networks fail.

In this contribution, I did not discuss the ways young deaf people grow up where deaf spaces or communities are not available, which is mostly the case in rural settings. Also, further exploration should look into the gender disparities regarding which pathways are open to whom. Additional research and analysis should be undertaken on the intergenerational dynamics among the deaf as well. Deaf communities and cultures around the world have their mythologies and ancestries. A simplistic denial of the 
elders' contributions will help the deaf cause as little as rejecting the new ideas of the young. I see the crucial challenge for the deaf communities in Benin in the lack of clear representation, the lack of a collective agency to discuss their identity and language issues, as well as to claim their rights toward the hearing society or the government. Despite and because of their interstitial positioning, Beninese deaf youth, as "a constant source of creativity, ingenuity, possibility, empowerment, a source of alternative, yet-to-be-imagined futures" (Comaroff \& Comaroff, 2005, p. 29), might be the ones to initiate deaf collective agency. After all, it is the future of the deaf communities that will be the future of the deaf youth in Benin.

\section{REFERENCES}

Abbink, J. (2005). Being young in Africa: The politics of despair and renewal. In J. Abbink \& I. van Kessel (Eds.), Vanguards or vandals. Youth, politics and conflict in Africa (pp. 1-34). Leiden, Netherlands: Brill.

African Union. (2006). African youth charter. Retrieved February 25, 2019, from https://au.int/sites/default/files/treaties/7789-treaty-0033_-_african_ youth_charter_e.pdf

Alber, E. (2018). Transfers of belonging: Child fostering in West Africa in the 20th century. Leiden, Netherlands: Brill.

Alber, E., Martin, J., \& Notermans, C. (Eds.). (2013). Child fostering in West Africa. New perspectives on theory and practices. Leiden, Netherlands: Brill.

Aoki, K., \& Feldman, M. W. (1991). Recessive hereditary deafness, assortative mating, and persistence of a sign language. Theoretical Population Biology, 39(3), 358-372.

Christiansen, C., Utas, M., \& Vigh, H. E. (2006). Introduction. In C. Christiansen, M. Utas, \& H. E. Vigh (Eds.), Navigating youth, generating adulthood: Social becoming in an African context (pp. 9-28). Uppsala, Sweden: The Nordic Africa Institute.

Comaroff, J., \& Comaroff, J. (2005). Reflections on youth from the past to the postcolony. In A. Honwana \& F. de Boeck (Eds.), Makers \& breakers. Children and youth in postcolonial Africa (pp. 19-30). Trenton, NJ: Africa World Press.

Davis, L. J. (1995). Enforcing normalcy: Disability, deafness, and the body. New York, NY: Verso.

Devlieger, P. (1999). Developing local concepts of disability: Cultural theory and research prospects. In B. Holzer, A. Vreede, \& G. Weigt (Eds.), Disability in different cultures: Reflections on local concepts (pp. 297-302). Piscataway, NJ: Transaction.

Diouf, M. (2003). Engaging postcolonial cultures: African youth and public space. African Studies Review, 46(2), 1-12. 
Erting, C. J., Johnson, R., Smith, D., \& Snider, B. (Eds.). (1994). The deaf way. Perspective from the international conference on deaf culture. Washington, DC: Gallaudet University Press.

Ette-Akre, E. (2012). Approche scientifique de la surdité [Scientific approach to deafness]. In Y. A. Sanogo (Ed.), Écoute mes mains - Dictionnaire de la langue des signes d'Afrique Francophone [Dictionary of the sign language of Francophone Africa] (pp. 17-34). Abidjan, Ivory Coast: Edilis.

Friedner, M. (2015). Valuing deaf worlds in urban India. New Brunswick, NJ: Rutgers University Press.

Friedner, M., \& Kusters, A. (Eds.). (2016). It's a small world. International deaf spaces and encounters. Washington, DC: Gallaudet University Press.

Ginsberg, F., \& Rapp, R. (2013). Disability worlds. Annual Review of Anthropology, $42,53-68$.

Goffman, E. (1963). Stigma - Notes on the management of spoiled identity. New York, NY: Simon and Schuster.

Goody, E. (1982). Parenthood and social reproduction. Fostering and occupational roles in West Africa. Cambridge, UK: Cambridge University Press.

Hacking, I. (2002). Historical ontology. Cambridge, MA: Harvard University Press.

Hacking, I. (2011). Between Michel Foucault and Erving Goffman. Between discourse in the abstract and face-to-face interaction. Economy and Society, $33(3), 277-302$.

Honwana, A., \& de Boeck, F. (Eds.). (2005). Makers \& breakers. Children and youth in postcolonial Africa. Trenton, NJ: Africa World Press.

Howell, S. (2003). Kinning: The creation of life trajectories in transnational adoptive families. Journal of the Royal Anthropological Institute, 9(3), 465-484.

Igwe, L. (2016). The witch is not a witch: The dynamics and contestations of witchcraft accusations in Northern Ghana (Doctoral dissertation). Retrieved October 23, 2018, from https://epub.uni-bayreuth.de/3377/

Jackson, M. (1995). At home in the world. Durham, NC: Duke University Press.

Jackson, M. (2010). Myths/stories/lives. In B. J. Good, M. M. J. Fischer, S. S. Willen, \& M. D. Good (Eds.), A reader in medical anthropology: Theoretical trajectories, emergent realities (pp. 137-142). Chichester, UK: Wiley-Blackwell.

Jenkins, R. (1996). Social identity. London, UK: Routledge.

Kamei, N. (2006). The birth of langue des signes Franco-Africaine: Creole ASL in West and Central French-speaking Africa. Sign Language Communication Studies, 59(3), 67-68.

Kiyaga, N., \& Moores, D. (2003). Deafness in sub-Saharan Africa. American Annals of the Deaf, 148(1), 18-24.

Kusters, A. (2015). Deaf space in Adamorobe. An ethnographic study in a village in Ghana. Washington, DC: Gallaudet University Press.

Lane, H. L. (2010). Construction of deafness. In L. J. Davis (Ed.), The disability studies reader (pp. 77-93). New York, NY: Routledge. 
Le Meur, P.-Y. (2008). Between emancipation and patronage: Changing intergenerational relationships in central Benin. In E. Alber, S. van der Geest, \& S. Reynolds Whyte (Eds.), Generations in Africa. Connections and conflicts (pp. 209-235). Berlin, Münster, Germany: LIT.

Martin, J., Ungruhe, C., \& Häberlein, T. (2016). Young future Africa - Images, imagination and its making. AnthropoChildren, Special Issue 6, 1-18.

McIlroy, G. (2010). Discovering deaf identities: A narrative exploration of school experiences on deaf identities. Saarbrücken, Germany: Lambert Academics.

McIlroy, G., \& Storbeck, C. (2011). Development of deaf identity: An ethnographic study. Journal of Deaf Studies and Deaf Education, 16(4), 494-511.

Monaghan, L. (2003). A world's eye view: Deaf cultures in global perspective. In L. F. Monaghan, C. Schmaling, K. Nakamura, \& G. H. Turner (Eds.), Many ways to be deaf. International variation in deaf communities (pp. 1-24). Washington, DC: Gallaudet University Press.

Nakamura, K. (2006). Deaf in Japan: Signing and the politics of identity. Ithaca, NY: Cornell University Press.

Neubert, D., \& Cloerkes, G. (2001). Behinderung und Behinderte in verschiedenen Kulturen. Eine vergleichende Analyse ethnologischer Studien [Disability and disabled people in different cultures. A comparative analysis of anthropological studies]. Heidelberg, Germany: Universitätsverlag Winter.

Nyst, V. (2010). Sign languages in West Africa. In D. Brentari (Ed.), Sign languages (pp. 405-432). Cambridge, UK: Cambridge University Press.

Padden, C. (1980). The Deaf community and the culture of Deaf people. In C. Baker \& R. Battison (Eds.), Sign language and the Deaf community. Essays in honor of William C. Stokoe (pp. 89-103). Washington, DC: National Association of the Deaf.

Philipps, J. (2018). A global generation? Youth studies in a postcolonial world. Societies, 8,14 .

Rush, D. (2013). Vodun in coastal Benin. Unfinished, open-ended, global. Nashville, TN: Vanderbilt University Press.

Sacks, O. (1989). Seeing voices: A journey into the world of the deaf. Berkeley/Los Angeles, CA: University of California Press.

Scheper-Hughes, N., \& Lock, M. (1987). The mindful body: A prolegomenon to future work in medical anthropology. Medical Anthropology Quarterly, $1(1), 6-41$.

Shakespeare, T. (2010). The social model of disability. In L. Davis (Ed.), The disability studies reader (pp. 266-273). New York, NY: Routledge.

Spittler, G. (2001). Teilnehmende Beobachtung als dichte Teilnahme [Participant observation as thick participation]. Zeitschrift für Ethnologie, 126, 1-25.

United Nations Educational, Scientific and Cultural Organization (UNESCO). (2017). What do we mean by 'youth'? Retrieved October 22, 2018, from http:// 
www.unesco.org/new/en/social-and-human-sciences/themes/youth/ youth-definition

VanGilder, K. (2016). Exploring the contours of DEAF-SAME kinship bonds and mutuality in United Methodist short-term missions. In M. Friedner \& A. Kusters (Eds.), It's a small world. International deaf spaces and encounters (pp. 140-149). Washington, DC: Gallaudet University Press.

Vigh, H. E. (2006). Navigating terrains of war. Youth and soldiering in GuineaBissan. New York, NY: Berghahn Books.

Vigh, H. E. (2010). Youth mobilisation as social navigation: Reflections on the concept of dubriagem. Cadernos de Estudos Africanos, 18(19), 139-164.

Vodounou, V. (2008). The incredible journeys of Victor Vodounou: Africa, deafness, and Christianity. El Cajon, CA: CSN Books.

World Health Organization. (2018, March). 10 facts about deafness. Retrieved February 25, 2019, from https://www.who.int/features/factfiles/ deafness/en/

Open Access This chapter is licensed under the terms of the Creative Commons Attribution 4.0 International License (http://creativecommons.org/licenses/ by $/ 4.0 /)$, which permits use, sharing, adaptation, distribution and reproduction in any medium or format, as long as you give appropriate credit to the original author(s) and the source, provide a link to the Creative Commons licence and indicate if changes were made.

The images or other third party material in this chapter are included in the chapter's Creative Commons licence, unless indicated otherwise in a credit line to the material. If material is not included in the chapter's Creative Commons licence and your intended use is not permitted by statutory regulation or exceeds the permitted use, you will need to obtain permission directly from the copyright holder.

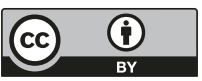

